\title{
Anti-Proliferative and Apoptotic Activity of Rumex obtusifolius seed's Hydroalcoholicextract on Human Colon Cancer Cell Line "SW480"
}

\author{
Ladan Badiee pourtaghi $^{1,4}$, Farahnaz Bineshian ${ }^{2}$, Bizhan Sadighi moghadam ${ }^{3}$, Raheb Ghorbani ${ }^{5}$ \\ $\&$ Hossein Nazari ${ }^{1}$ \\ ${ }^{1}$ Department of Biochemistry, Semnan University of Medical Sciences, Semnan, Iran \\ ${ }^{2}$ Department of Parasitology and Mycology, Semnan University of Medical Sciences, Semnan, Iran \\ ${ }^{3}$ Department of Immonulogy, Semnan University of Medical Sciences, Semnan, Iran \\ ${ }^{4}$ Student Research Committee, Semnan University of Medical Sciences, Semnan, Iran \\ ${ }^{5}$ Social Determinants of Health Research Canter, Semnan University of Medical Sciences, Semnan, Iran \\ Correspondence: Hossein Nazari, Department of Biochemistry, Semnan University of Medical Sciences, Semnan, \\ Iran. Tel: +98-233-3353-1703. E-mail: hosnazbio@yahoo.com
}

Received: May 28, 2019

doi:10.5539/jmbr.v9n1p111
Accepted: September 20, 2019

Online Published: October 23, 2019

\begin{abstract}
Cancer is considered a serious threat to human health thatcolon cancer is the third most common cancer in the world. Colon cancer has undergone significant growth worldwide in recent years, and many people die every year as a result of this disease, which its treatment is a major challenge for researchers. In this study, we investigated the effect of anti-proliferative and apoptotic activity seed's hydroalcoholic extract of Rumex obtusifolius, "is native to Semnan's northern region" on the human colon cancer cell line, SW480.

The SW480 human colon cancer cell line were cultured in RPMI 1640 cell culture containing $10 \%$ Fetal bovine Serum and $1 \%$ Penicillin and Streptomycin antibiotics and incubated with a relative humidity of $95 \%$, carbon dioxide $5 \%$ at $37^{\circ} \mathrm{C}$. The SW480 cancer cell line was cultured in 48 and 96 well plates and treated with different concentrations of seeds hydroalcoholic extract of Rumex obtusifolius $(20 / 40 / 80 / 160 / 320$ micrograms $/ \mathrm{ml})$ for evaluation of cell viability by Trypan blue exclusion method and MTT assay. A non-treated group was used as control and a treated group with DMSO was used as solvent in solution of powdered extract as vehicle as well as positive control groups. Also, cell apoptosis assessment was performed by Propideum iodide/Annexin V test "Flowcytometry"and DNA fragmentation analysis "Agaros electrophoresis".

Seed hydroalcoholic extract caused cell death at concentrations of 40, 80, 160 and $320 \mu \mathrm{g} / \mathrm{ml}$, which the anticancer effect trend to increase significantly from $80 \mu \mathrm{g} / \mathrm{ml}$. The effect of R. obtusifolius seed extract even has more anticancer effect in 160 and $320 \mu \mathrm{g} / \mathrm{ml}$ than cells which is treated to $5 \mathrm{FU}$ as a positive control groups.

Seed hydroalcoholic extract reduced cell viability in proportion concentration. The effect of anticancer activity of seed extract trend to increase from $40 \mu \mathrm{g} / \mathrm{ml}$ but it was shown effective concentrations for inhibiting of the cells growth were $160,320 \mu \mathrm{g} / \mathrm{ml}$ in $48 \mathrm{hr}$ incubation time and 80,160 and $320 \mu \mathrm{g} / \mathrm{ml}$ in $72 \mathrm{hr}$ incubation time. Also, the effect of this extract at concentrations of 160 and $320 \mu \mathrm{g} / \mathrm{ml}$ with control group is not significant which have more cytotoxicity and even extract can have a significant effect on decreasing the survival of the SW480 cells. The data generated by flow cytometry are shown that colon cancer cells trend to necrosis and apoptotic pathway from $40 \mu \mathrm{g} / \mathrm{ml}$ and increased significantly entrance to apoptotic pathway from $80 \mu \mathrm{g} / \mathrm{ml}$ which is confirm the Trypan blue and MTT assay tests. Since the appearance of the DNA fragmentation, which precedes the bioavailability change, is characteristic to apoptosis, the extracts were considered to be apoptosis-inducers. The ability to inhibit growth and induction of apoptosis in SW480 cancer cells is a concentration- and time dependent manner. These results indicated that the induction of apoptosis at least partly mediates their cytotoxic activity which is necessary down further study for elucidation apoptotic signaling pathway.
\end{abstract}

Keywords: Rumex obtusifolius Seeds, Apoptosis, Annexin V, SW480 Cell Line

\section{Introduction}

Cancer refers to a disease caused by uncontrolled growth, outside the control of the cells that has the ability to 
attack and spread to other parts of the body which can involve adjacent tissues (Somasundaram, Shanmugam, Subramanian, \& Jaganathan, 2016). Cancer is a group of diseases characterized by unregulated growth of cells, invasion and spread of cells from site of origin or primary site, to other sites in the body (Imad Uddin, Rachana, Suraj, Naveena, \& Mounica, 2019). In 2018, Cancer was the second major reason of death globally, and was the cause of an estimated 9.6 million deaths; worldwide, about $17 \%$ of deaths was caused by cancer (Al-Harbi, Awad, Alsberi, \& Abdein, 2019). Cancer is considered a serious threat to human health (Pan et al., 2017) that colon cancer is the third most common cancer in the world (Carini et al., 2017). Colon cancer is the growth of malignant cells in the large intestinal tissue, the cause of colon cancer, like other cancers, is not clear, but the environmental and genetic factors play an important role in the incidence of this cancer, and are risk factors for it (Armstrong, Mathers, \& Pot, 2000; C. F. Garland \& F. Garland, 1980). Colon cancer has undergone significant growth worldwide in recent years, and many people die every year as a result of this disease, which its treatment is a major challenge for researchers (Vaiopoulos, Athanasoula, \& Papavassiliou, 2014). Colon cancer is the third most prevalent cancer in the world, nearly one million new cases of colon cancer are diagnosed annually, and about one million deaths are caused by it each year (Alsayed, Surrati, Altaifi, Alharbi, Alfouti, \& Alremaithi, 2019).

There are different therapeutic approaches to cancer, including chemotherapy, surgery, radiation therapy, which, in addition to high costs, can have harmful effects on the health cells, and in many cases they cannot be addressed. In addition, the use of synthetic drugs has limitations due to high toxic effects and increased resistance of cancer cells (Bergers \& Hanahan, 2008; Gong et al., 2016). And the defects in the common cancer treatment methods referred to have led researchers to find new ways in cancer treatment.

The use of drugs derived from plants, due to its low toxicity, high effectiveness, inexpensive and availability can be an effective way of treating cancer and serious illness that use of these drugs can dramatically reduce the incidence of conventional cancer treatment methods (Cheng et al., 2016).

Herbal remedies have been used for treating diseases for many years. Recently, plant materials or their extracts as substitute and supportive medicine have been used increasingly (Shertayeva, Sabiraliyeva, Taubayeva, \& Taithibekov, 2018). One of the plants that can be used to treat cancer is Rumex or Sorrel (Kim \& Lee, 2016; Vasas, Orbán-Gyapai, \& Hohmann, 2015). The plant belongs to the Polygonaceae family, whose various species have been scattered throughout the world. Research has shown that this plant has various drug activities (Vasas, OrbánGyapai, \& Hohmann, 2015). The plant has high levels of secondary metabolites, includinganthraquinone, steroids, glycosides, flavonoids, lucoantiocyanidins, and phenolic acids, and research has shown that it has anti-proliferative effect on cancer cells and also induces apoptosis in cancer cells (Vasas, Orbán-Gyapai, \& Hohmann, 2015; Wegiera, Smolarz, \& Bogucka-Kocka, 2012; Xie \& Yang, 2014). Apoptosis is a process that eliminates old, harmful and damaged cells and is essential for homeostasis, and any disorder in the process of apoptosis can lead to cancer (Elmore, 2007; Ashkenazi, Holland, \& Eckhardt, 2008). Therefore, therapies that induce apoptosis in cancer cells can be an effective way to treat cancer (Lowe \& Lin, 2000). During apoptosis, cellular changes occur, including cell wrinkling, DNA fragmentation, phosphatidyl serine displacement from the inner layer of the cell membrane to the outer layer, which can be evaluated for the incidence of apoptosis (Elmore, 2007). Considering the mentioned issues, the importance of colon cancer and the regulatory role of apoptosis in the treatment of cancer, in this study, we investigated the effect of anti-proliferative and apoptotic activity seed'shydroalcoholic extract of Rumexobtusifolius, "is native to Semnan's northern region" on the human colon cancer cell line, SW480.

\section{Material and Method}

\subsection{Materials}

Trypan blue, Penicillin-Streptomycin, DMSO, 3-[4,5-dimethylthiazol-2-yl]-2,5-diphenyl tetrazolium bromide "MTT" were purchased Sigma-Aldrich, USA, 0.05\% Trypsin-EDTA from BIO-IDEA, Roswell Park Memorial Institute medium (RPMI) 1640 from Biowest, Fetal Bovine Serum (FBS) were purchased from Gibco, DNA extraction kit and 1kb DNA Ladder from Sinacolone (Cat. No.: PR881613), other material and solvents used in the present work were purchased from Merck, Germany.

\subsection{Preparation of Plant Extracts}

Seeds of Rumexobtusifolius were investigated which is collected from Semnan city and approved by specialists of the Center for Applied Scientific Practice of the University ofSemnan Province. The plant transferred to the laboratory and was dried in ideal condition after well washing. These are extracted with ethylacetate, methanol, water solvent (60-30-10) by Soxhlet system. Extract was concentrated by rotary evaporator system and the dried powder was stored in a containertill was completely dissolved in the proper proportions of DMSO and PBS used to prepare drug concentrations. 


\subsection{Cell Viability Assessment}

\subsubsection{Cell Culture}

The SW480 human colon cancer cell line was purchased from cell Bank of Pasteur Institute's Tehran with NCBI code "C509". Cells were cultured in RPMI 1640 (BIO-IDEA IRAN) cell culture containing 10\% Fetal bovine Serum (BIO-IDEA IRAN) and $1 \%$ Penicillin and Streptomycin antibiotics and incubated with a relative humidity of $95 \%$, carbon dioxide $5 \%$ at $37^{\circ} \mathrm{C}$. The SW 480 cancer cell line was cultured in 48 and 96 well plates and treated with different concentrations of seeds hydroalcoholic extract of Rumex obtusifolius (20/40/80/160/320 micrograms $/ \mathrm{ml}$ ) for evaluation of cell viability. Also, a non-treated group was used as control and a treated group with DMSO was used as solvent in solution of powdered extract as vehicle as well as positive control groups (5FU, $100 \mu \mathrm{g} / \mathrm{ml})$.

\subsubsection{Trypan Blue Exclusion Method}

Estimation of cell survival rate was performed by trypan blue test. Evaluation of trypan blue dye penetration into cancerous cell and counting dead and living cells was done. Using neobar lam and optical microscope. In this test, living cells remain colorless due to possess resistantand intact membrane that exclude dye, whereasdead cells that have lost their resistance become blue (nucleus and cytoplasm) which indicates the effectiveness of the extract on cancer cells. The SW480 cancer cells were cultured in 48 well plates and after reaching a sufficient density treated with different concentrations of Rumexo btusifolius seeds hydroalcoholic extract $(20 / 40 / 80 / 160 / 320 \mu \mathrm{g} / \mathrm{ml})$. 24 , 48 and 72 hours after treatment, the cells trypsinizedand subjected to cell suspension centrifugation in a fresh culture medium. $10 \mu \mathrm{l}$ of cell suspension with $10 \mu \mathrm{l}$ of $0.4 \%$ trypan blue color were combined at for one to three minutes. Then, $10 \mu \mathrm{l}$ of samples was taken on a neobar lamella and live and dead cells counted with the optical microscope.

\subsubsection{MTT Assay}

In order to study the effect of Rumexobtusifoliushydroalcoholic extract on the SW480 cell line, MTT colorimetric method was used. This method is based on the ability of converting of water soluble MTT toaninsolubleformazans crystalline by living cells. Formazancrystals are dissolved in DMSO and absorbed at $570 \mathrm{~nm}$. The tetrazolium yellow color converted to formazan purple crystals after being introduced into mitochondrial enzymes. The number of live cells is directly dependent to the absorbance of light. In order to perform this test, SW480 cells "5000 cells/well" were cultured in 96 well plates and incubated at $37^{\circ} \mathrm{C}$ for 24 hours. The wells were treated with concentrations of $(20 / 40 / 80 / 160 / 320 \mu \mathrm{g} / \mathrm{ml})$ Rumexobtusifoliusseeds hydroalcoholic extract when cells reached to $80 \%$ confluences. 10 micrograms of MTT dissolved insterile PBS $(5 \mathrm{mg}$ per $1 \mathrm{ml})$ were added to the wells after $24 / 48 / 72$ hoursand incubated the plate for 3 hours in out of light at $37^{\circ} \mathrm{C}$. Then, the DMSO as a solvent of insoluble formazan crystals were added to the wells, and the absorbance of each well was read with an ELISA reader at $570 \mathrm{~nm}$.

\subsection{Cell Apoptosis Assessment}

\subsubsection{Propideum Iodide/Annexin V Test}

One of the methods for studying and identifying apoptosis is to investigate changes in the position of phosphatidyl serine in the cytoplasmic membrane. In the early stages of apoptosis, phosphatidyl serine is placed on the outer surface from the inner surface of the plasma membrane. Annexin $\mathrm{V}$ is a protein that attaches to phosphatidyl serine in the presence of calcium. For this test, cells were cultured "about 3,000 cells/well" in 6 well plate and were incubated for 24 hours at $37^{\circ} \mathrm{C}$. Cultured cells were treated with concentrations of $(40 / 80 / 160 / 320 \mu \mathrm{g} / \mathrm{ml})$ Rumex obtusifolius seeds hydroalcoholic extract. The cells were trypsinized and separated from the wells after 48 and 72 hours incubation, and washed twice with PBS buffer, and then a binding buffer containing calcium ion as well as an Annexin V FITC (biolegend) and PI color was added to the tube before incubation in the dark place for 20 minutes. The samples were read by the BD-FACS caliber flow cytometry and flowmax software was used to analyze the data.

\subsubsection{DNA Fragmentation}

One of the most significant biochemical properties of apoptosis is the fragmentation of DNA by a specific nuclease called Caspase-activated Dnase (CAD). In order to investigate the DNA fragmentation test, SW480 cancer cells were treated with different concentrations of seeds extract $(40 / 80 / 160 / 320 \mu \mathrm{g} / \mathrm{ml})$ and the cells were trypsinized and were washed by PBSafter 48 hours. The cells were then lysed by lysis buffer, and DNA was extracted according to the Sinacolon kit's procedure. Then the extracted DNA was electrophoreses on $1.5 \%$ agarose gel and was detected by gel doc device. 


\subsection{Statistical Analysis}

The data were expressed as means $\pm \mathrm{SE}$. The statistical differences between groups were examined using standard statistical methods of one-way ANOVA followed by Student's t test with the SPSS 22.0 software, and statistical differences were considered significant at the $\mathrm{P}<0.05$ level.

\section{Results}

\subsection{Determination of Cell Viability of R. obtusifolius Seeds Extract by Trypan Blue Assay}

In order to investigate the effect of growth inhibition and the anti-cancer of $R$. obtusifoliushydroalcoholic extract, SW480 cells "human colon cancer cell line" seeded in 48-well plates and were treated with various concentrations of seedhydroalcoholic extract for 24, 48 and 72 hour and assessed cell death using Trypan blue exclusion assay. As shown in Figure 1, seed hydroalcoholic extract caused cell death in proportion concentration. $R$. obtusifoliusseed extract has significantanti-cancer effecton colon cancer cells. $R$. obtusifolius seed extract induces dose - and time - dependent cell death on SW480 cancer cells. After counting live and dead cells by neobar lam, the percent viability of the cells was calculated by the following formula:

$$
\text { Cell viability percentage }=(\text { live cell number }) /(\text { Total cell number }) \times 100
$$

The data represent three independent experiments carried out in triplicate and expressed as mean $\pm \mathrm{SE}$.

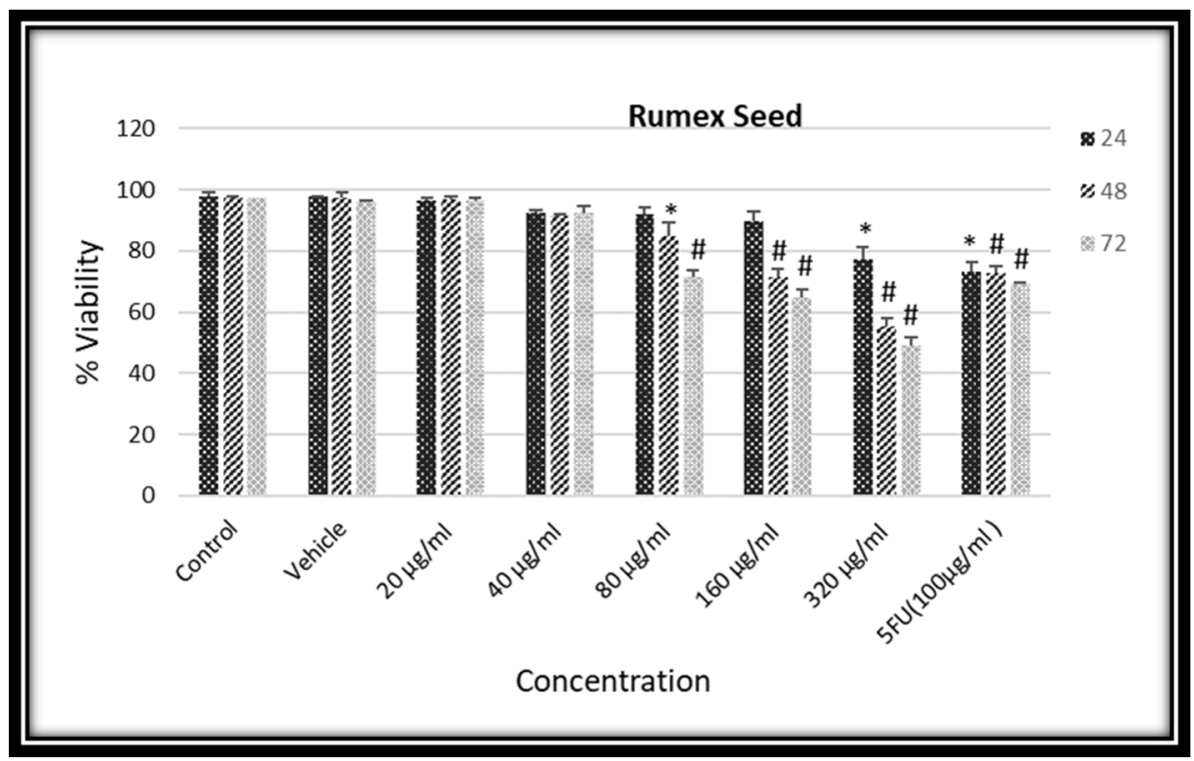

Figure 1. The effect of Rumex Seed extract on cell death

SW480 cells were exposed to hydroalcoholic extract of $R$. obtusifolius with concentrations of 20,40, 80, 160 and

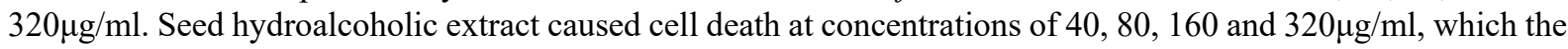
anticancer effect trend to increase significantly from $80 \mu \mathrm{g} / \mathrm{ml}$. The effect of $R$. obtusifolius seed extract even has more anti-cancer effect in 160 and $320 \mu \mathrm{g} / \mathrm{ml}$ than cells which is treated to $5 \mathrm{FU}$ as a positive control groups. The results are three times the independent repetition with $* \mathrm{P} \leq 0.05$, \# $\mathrm{P} \leq 0.001$.

\subsection{Assessment of Cytotoxicity by MTT Assay}

Cells seeded on 96 -well plates $\left(5 \times 10^{3}\right.$ cells/well) were treated with the indicated concentrations of hydroalcoholic extract of R. obtusifolius for 24, 48 and 72 hour, and the relative cell viability was assessed using MTT assay. As shown in Figure 2 seedhydroalcoholic extract reduced cell viability in proportion concentration. The effect of anticancer activity of seed extract trend to increase from $40 \mu \mathrm{g} / \mathrm{ml}$ but it was shown significantly from $80 \mu \mathrm{g} / \mathrm{ml} \mathrm{in}$ $72 \mathrm{hr}$ incubation time and $160 \mu \mathrm{g} / \mathrm{mlfrom} 48 \mathrm{hr}$ incubation time which has significantly effect in $320 \mu \mathrm{g} / \mathrm{ml}$ compared to positive control groups. 


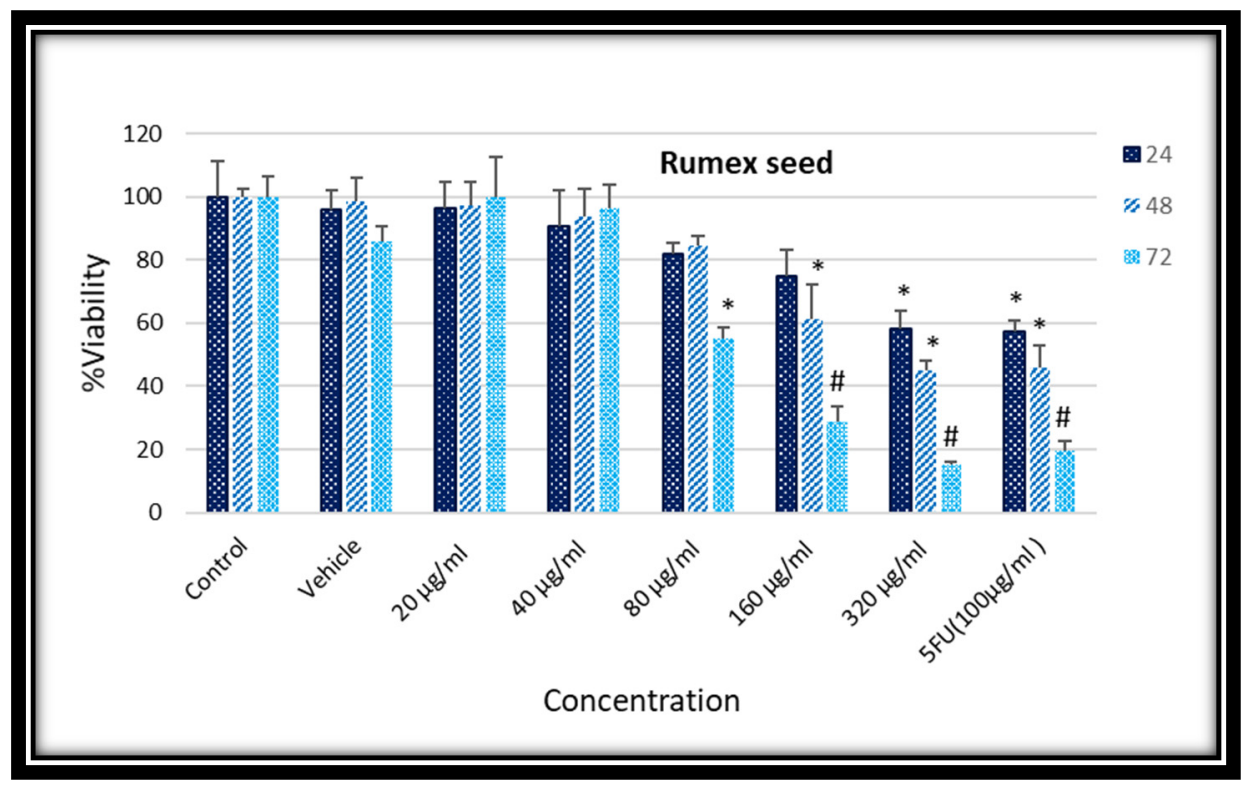

Figure 2. The effect of Rumex Seed extract on cell viability

SW480 cells were exposed to hydroalcoholic extract of $R$. obtusifolius with concentrations of 20, 40, 80, 160 and $320 \mu \mathrm{g} / \mathrm{ml}$. Seed hydroalcoholic extract caused cell death at concentrations of $40,80,160$ and $320 \mu \mathrm{g} / \mathrm{ml}$, which the anticancer effect trend to increase significantly from $80 \mu \mathrm{g} / \mathrm{ml}$ in $72 \mathrm{hr}$ and up to $160 \mu \mathrm{g} / \mathrm{ml} \mathrm{in} 48 \mathrm{hr}$ incubation time. The effect of R. obtusifolius seed extract even has more anti-cancer effect in $320 \mu \mathrm{g} / \mathrm{ml}$ at $72 \mathrm{hr}$ incubation time than cells which is treated to $5 \mathrm{FU}$ as a positive control groups. The results are three times the independent repetition with $* \mathrm{P} \leq 0.05$, \# $\mathrm{P} \leq 0.001$.

\subsection{The Effect of Rumex Seed Extract on Apoptosis}

To detected cell apoptosis, Annexin V/PI double staining kit (biolegend) has been used in flowcyto-fluorimetric analyses. The Annexin V corresponding signal provides a very sensitive method for detecting cellular apoptosis, while propidium iodide (PI) is used to detect necrotic or late apoptotic cells, characterized by the loss of the integrity of the plasma and nuclear membranes. The data generated by flow cytometry are plotted in twodimensional dot plots in which PI is represented versus Annexin V-FICT as shown in Figure 3. These plots can be divided in four regions corresponding to:

1) Viable cells which are negative to both probes Q4: (PI-/FITC-);

2) Apoptotic cells which are PI negative and Annexin positive Q3: (PI-/FITC+);

3) Late apoptotic cells which are PI and Annexinpositive Q2: (PI+/FITC+);

4) Necrotic cells which are PI positive and Annexin negative Q1: (PI+/FITC-).

Cells were cultured in 6 well plate and were incubated for 24 hours at $37^{\circ} \mathrm{C}$. Cultured cells were treated, the plant seeds hydroalcoholic extract with concentrations of $40 / 80 / 160 / 320 \mu \mathrm{g} / \mathrm{ml}$ after 24 hours. The data generated by flow cytometry are shown that colon cancer cells trend to necrosis and apoptotic pathway from $40 \mu \mathrm{g} / \mathrm{ml}$ and increased significantly entrance to apoptotic pathway from $80 \mu \mathrm{g} / \mathrm{ml}$ which is confirm the Trypan blue and MTT assay tests.

\subsection{The Effect Rumexhydoalcoholic Extract on DNA Fragmentation}

R. obtusifolius seeds extract in dose 160 and $320 \mu \mathrm{g} / \mathrm{ml}$ was the most toxic substance against SW480 cells at $48 \mathrm{hr}$. Seeds extract samples have some extend cell death which is more significant in seeds extract from $160 \mu \mathrm{g} / \mathrm{ml}$ which were suggested to play an important role for cytotoxic activity. Polyphenols which is extracted in hydroalcoholic solvent were reported as apoptosis-inducer against K562 and MKN-45 (Wegiera, Smolarz, \& Bogucka-Kocka, 2012; Ashkenazi, Holland, \& Eckhardt, 2008). Here, we investigated whether R. obtusifolius hydroalcoholic extract induced apoptosis against SW480. DNA ladders appeared in $48 \mathrm{hr}$ after incubation of the cells with extract samples as shown in Figure 4. Since the appearance of the DNA fragmentation, which precedes the bioavailability change, is characteristic to apoptosis, the extracts were considered to be apoptosis-inducers. These results indicated that the induction of apoptosis at least partly mediates their cytotoxic activity. 


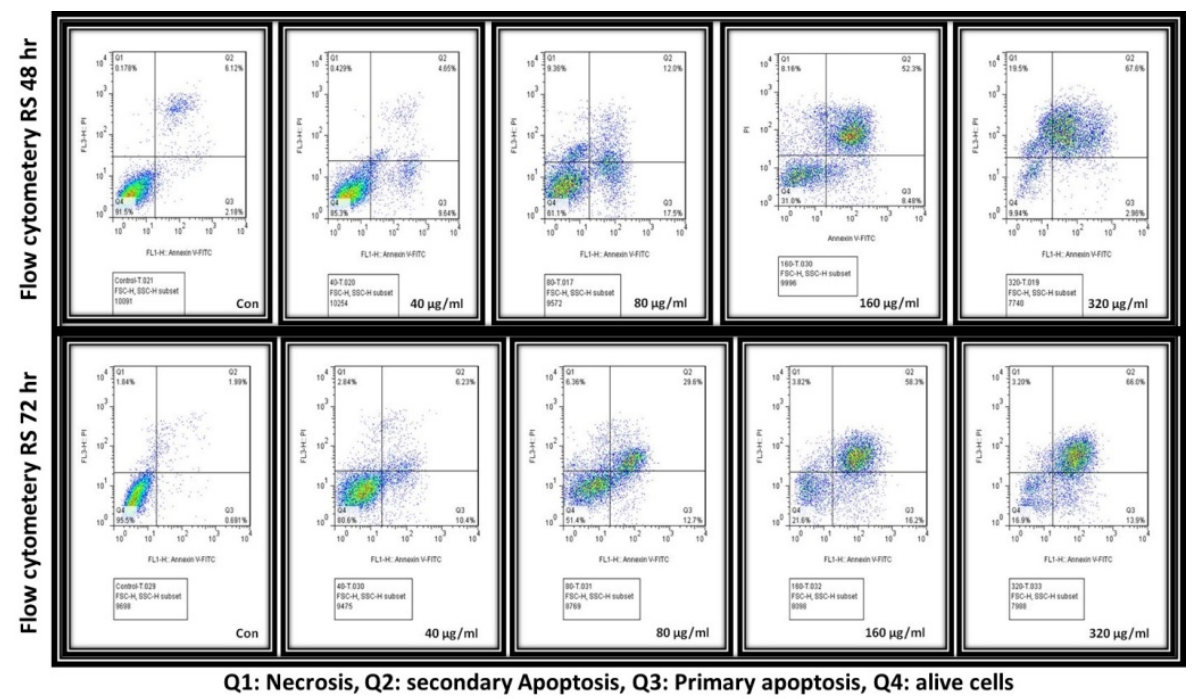

Figure 3. The effect of Rumex Seed extract on apoptosis

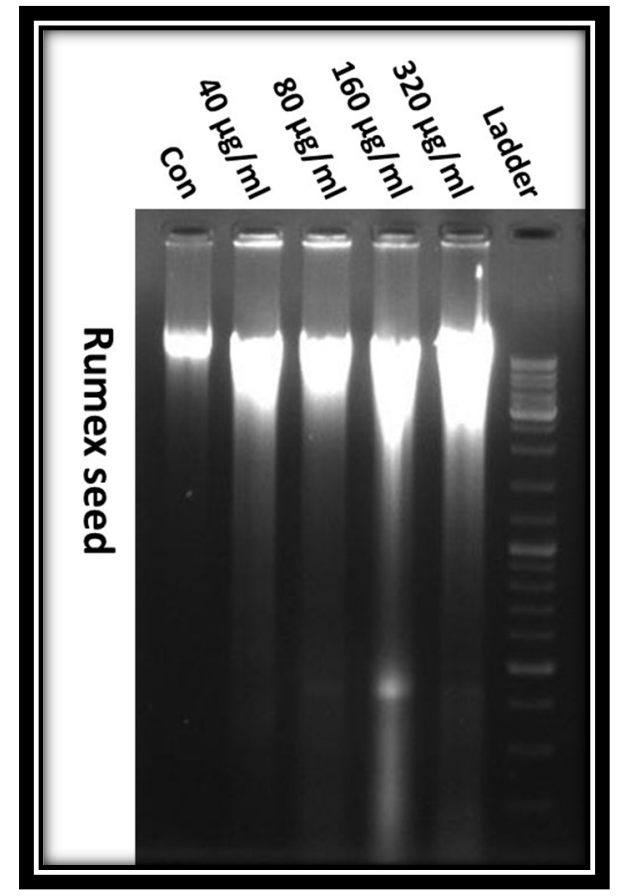

Figure 4. The effect of Rumex Seed extract on DNA fragmentation

Cells were cultured in 6 well plate and were incubated for 24 hours at $37^{\circ} \mathrm{C}$. SW480 cultured cells were treated, the plant seeds hydroalcoholic extract with concentrations of 20/40/80/160/320 $\mathrm{g} / \mathrm{ml}$ after 48 hours. The cells were then lysed by lysis buffer after trypsinized and were washed by PBS after 48 hoursincubation time. DNA was extracted according to the Sinacolon kit's procedure. The data generated by electrophoresis are shown that colon cancer cells DNA trend to fragmentation from $40 \mu \mathrm{g} / \mathrm{ml}$ and increased significantly fragmented from $80 \mu \mathrm{g} / \mathrm{ml}$ which can see more smear and small size separated bands in the gel.

\section{Discussions}

The aim of this study was to determine the anti-tumor effects of hydroalcoholic extract of Rumex obtusifolius seed on the SW480 cancer cell line. The toxicity of the hydroalcoholic extract of Rumexobtusifolius seed on the SW480 cancer cells was performed by trypan blue and MTT assay for concentrations of 20, 40, 80, 160 and $320 \mu \mathrm{g} / \mathrm{ml}$ at 24, 48 and 72 hours. The results of trypan blue and MTT assay showed that the hydroalcoholic extract of Roomex 
seed is time and dose-dependent manner, could inhibit the growth and proliferation of SW480 cells and have a relatively high degree of toxicity in the concentration 80,160 and $320 \mu \mathrm{g} / \mathrm{ml}$ compared to the control group. Also, there was no significant difference between the groups treated with $5 \mathrm{FU}$, "one of the common drugs in chemotherapy" which have high level of cell death on human colorectal cancer cells. WEGIERA et al. (2012) examined the toxicity of ethanolic extracts of six species of the Rumex plant, including Rumexobtusifolius, on cancer cells of 1301 (human T-cell lymphoblastic leukemia), EOL-1 human eosinophilic leukemiaas well as H9 cell line (T-cell normal human) through the Trypan Blue test. The results indicated that all herbal extracts had toxicity effects on these cell lines which our research data is the same (Wegiera, Smolarz, \& Bogucka-Kocka, 2012).

Chao et al. in 2014, Rumex Japunicus's anticancer activity on lung cancer cells "A549 cell line" was measured by the MTT test. Concentrations of 5 to $80 \mu \mathrm{g} / \mathrm{ml}$ of the extract were treated on the cells for 24 and 48 hours. And observed significant toxicity and fatalities at concentrations of 20,40 and $80 \mu \mathrm{g} / \mathrm{ml}$, that IC50 was estimated at 24 hours of $53.1 \mu \mathrm{g} / \mathrm{ml}$ and 48.3 hours after treatment with $27.31 \mu \mathrm{g} / \mathrm{ml}$ (Xie \& Yang, 2014).

The occurrence of apoptosis in the cell is associated with certain morphological changes, including small and wrinkled cells, loss of cell adhesion, cellular contraction, and transfer of Phosphatidyl serine from the inner half of the membrane to the outer half of the membrane and also increase expression of caspases and DNA fragmentation has been mentioned. As a result, any of these changes can help us diagnose the occurrence of apoptosis in the cell. In the present study, an Annexin V/PI test and assessment of DNA fragmentation were used to determine apoptosis in cancer cells. Because of the first symptoms of apoptosis is changes in the position of membrane phospholipids and changes in permeability of the membrane, to evaluate the apoptosis of Annexin V propidium iodide test was performed. In apoptotic cells, the best evidence of the occurrence of apoptosis is the transfer of phosphatidyl serine from the inner half of the membrane to the outer half of the membrane, which phospholipid attaches to the Annexin V protein in the presence of calcium. The results of this test showed that hydro-alcoholic extract of Rumexobtusifolius seeds in comparison with the control group can induce apoptosis, especially late apoptosis, in cancer cells. The results show that in the control group more than $90 \%$ of the cells are alive and 48 hours after treatment SW480 cells with concentrations of 40 to $320 \mu \mathrm{g} / \mathrm{ml}$ of hydroalcoholic extract, compared to the control group at concentrations $160 \mu \mathrm{g} / \mathrm{ml}(69.78 \%$ apoptosis) and $320 \mu \mathrm{g} / \mathrm{ml}$ (70.56 apoptosis) were induced in apoptosis in more than $50 \%$ of the cells. In 72 hours after treatment SW480 cells at $160 \mu \mathrm{g} / \mathrm{ml}$ $(70.4 .5 \%)$ and $320 \mu \mathrm{g} / \mathrm{ml}(79.9 \%)$ wee occurred, apoptosis was induced in more than $50 \%$ of the cells, and also at a concentration of $80 \mu \mathrm{g} / \mathrm{ml}$ about $50 \%$ of cells $(42.3 \%$ ) is induced by apoptosis. Tariq et al. (2011) shown that alcoholic and chloroform extracts of Rumex dentatus have the anti-proliferative effect and apoptosis inductionon MDA-MB-231, a breast cancer cell line by Annexin V test. The concentration of appropriate cytotoxicity effect on the cells was 120 and $180 \mu \mathrm{g} / \mathrm{ml}$ for alcoholic extract, and 90 and $135 \mu \mathrm{g} / \mathrm{ml}$ for chloroform extract, its decreases survival and increases apoptosis in these cells is concentration and time dependent manner which is agree with present data (Batool, Aziz, Tan, \& Mahmood, 2017). As stated above, other events and cell changes during apoptosis are fragmentation of DNA, which occurs as a result of caspase cascade activation. During the activation of the pathway of apoptosis, caspases enter active state and causes activation of a specific nuclease "CAD" and then this nuclease digests the DNA rapidly in nucleosomes. The results of the DNA fragmentation test showed that the DNA of cancer cells treated with $R$. obtusifolius seeds hydroalcoholic extract were observed as smear and separate bands in comparison with the control group on the agarose gel.

\section{Conclusion}

Based on the results of this study, it can be said that in vitro, the seeds hydroalcoholic extract of Rumex obtusifolius has the ability to inhibit growth and induction of apoptosis in SW480 cancer cells in a concentration- and time dependent manner. Effective concentrations for inhibiting the growth of the cells were $160,320 \mu \mathrm{g} / \mathrm{ml} \mathrm{in} 48 \mathrm{hr}$ incubation time and 80,160 and $320 \mu \mathrm{g} / \mathrm{ml}$ in $72 \mathrm{hr}$ incubation time. Also, the effect of this extract at concentrations of 160 and $320 \mu \mathrm{g} / \mathrm{ml}$ with $5 \mathrm{FU}$, the most commonly used chemotherapy drug, is not significant which have more cytotoxicity and this extract can have a significant effect on decreasing the survival of the SW480 cells. Also, it was determined in this study that the seeds hydroalcoholic extract of plant had induction of apoptosis in colorectal cancer cells by flow cytometry (Annexin/Propiodium iodide) test and DNA fragmentation analysis.

\section{Acknowledgement}

We would like to thank Semnan University of Medical Sciences for financial supporting and their cooperation and providing the facilities for this work.

\section{Conflict of interests}

The authors declare that there is no conflict of interests regarding the publication of this paper. 


\section{References}

Al-Harbi, N. A., Awad, N. S., Alsberi, H. M., \& Abdein, M. A. (2019). Apoptosis Induction, Cell Cycle Arrest and in Vitro Anticancer Potentiality of Convolvulus Spicatus and Astragalus Vogelii. World Journal of Environmental Biosciences, 8(4), 69-75.

Alsayed, M. A., Surrati, A. M., Altaifi, J. A., Alharbi, A. H., Alfouti, R. O., \& Alremaithi, S. M. (2019). Public Awareness of Colon Cancer Symptoms, Risk Factor, and Screening at Madinah- KSA. Int. J. Pharm. Res. Allied Sci., 8(1), 184-197.

Armstrong, F., Mathers, J. J., \& Pot, N. S. (2000). Kill and cure: Dietary augmentation of immune defences against colon cancer, 59(2), 215-20.

Ashkenazi, A., Holland, P., \& Eckhardt, S. (2008). Ligand-based targeting of apoptosis in cancer: The potential of recombinant human apoptosis ligand 2/tumor necrosis factor-related apoptosis-inducing ligand (rhApo2L/TRAIL), 26(21), 3621-30.

Batool, R., Aziz, E., Tan, B. K.-H., \& Mahmood, T. (2017). Rumex dentatus Inhibits Cell Proliferation, Arrests Cell Cycle, and Induces Apoptosis in MDA-MB-231 Cells through Suppression of the NF- $\kappa B$ Pathway, 8, 731.

Bergers, G., \& Hanahan, D. (2008). Modes of resistance to anti-angiogenic therapy. Nat Rev Cancer, 8(8), 592603.

Carini et al. (2017). Colorectal carcinogenesis: Role of oxidative stress and antioxidants, 37(9), 4759-66.

Cheng et al. (2016). Inhibitory effecton HT-29 colon cancer cells of a water-soluble polysaccharide obtained from highland barley, 92, 88-95.

Elmore, S. (2007). Apoptosis: A review of programmed cell death, 35(4), 495-516.

Garland, C. F., \& Garland, F. (1980). Do sunlight and vitamin D reduce the likelihood of colon cancer?(Vol. 9, No. 3, pp. 227-31).

Gong et al. (2016). Combined treatment with vitamin $C$ and sulindac synergistically induces p53-and ROSdependent apoptosis in human colon cancer cells, 258, 126-33.

Imad Uddin, M. D., Rachana, N., Suraj, N., Naveena, N., \& Mounica, P. (2019). Screening anti-cancer activity of colchicine loaded chitosan nanoparticles. Pharmacophore, 10(2), 37-42.

Kim, K., \& Lee, S. (2016). Healing. Remission of Unresectable Lung Metastases from Rectal Cancer After Herbal Medicine Treatment: A Case Report, 12(4), 259-62.

Lowe, S. W., \& Lin, A. (2000). Apoptosis in cancer, 21(3), 485-95.

Pan et al. (2017). miR-134: A human cancer suppressor? (Vol. 6, pp. 140-9).

Shertayeva, N., Sabiraliyeva, Z., Taubayeva, R., \& Taithibekov, A. (2018). Polyphenolic Compouds of Plant of Lepidium Ruderale Linn. and Their Biololical Activity. J Biochem Tech, 8(4), 77-80.

Somasundaram, S. N., Shanmugam, S., Subramanian, B., \& Jaganathan, R. (2016). Cytotoxic effect of fucoidan extracted from Sargassum cinereum on colon cancer cell line HCT-15, 91, 1215-23.

Vaiopoulos, A. G., Athanasoula, K. C., \& Papavassiliou, A. (2014). Epigenetic modifications in colorectal cancer: Molecular insights and therapeutic challenges, 1842(7), 971-80.

Vasas, A., Orbán-Gyapai, O., \& Hohmann, J. (2015). The Genus Rumex: Review of traditional uses, phytochemistry and pharmacology, 175, 198-228.

Wegiera, M., Smolarz, H. D., \& Bogucka-Kocka, A. (2012). Rumex L. species induce apoptosis in 1301, EOL-1 andH-9 cell lines, 69(3), 487-99.

Wegiera, M., Smolarz, H. D., \& Bogucka-Kocka, A. (2012). Rumex L. species induce apoptosis in 1301, EOL-1 and H-9 cell lines, 69, 487-99.

Xie, Q.-C., \& Yang, Y.-P. (2014). Medicine a. Anti-proliferative of physcion 8-O- $\beta$-glucopyranoside isolated from Rumex japonicus Houtt. on A549 cell lines via inducing apoptosis and cell cycle arrest, 14(1), 377.

\section{Copyrights}

Copyright for this article is retained by the author(s), with first publication rights granted to the journal.

This is an open-access article distributed under the terms and conditions of the Creative Commons Attribution license (http://creativecommons.org/licenses/by/4.0/). 